\title{
Artificial MicroRNA-Based Specific Gene Silencing of Grain Hardness Genes in Polyploid Cereals Appeared to Be Not Stable Over Transgenic Plant Generations
}

\author{
Sebastian Gasparis ${ }^{1}$, Maciej Kała ${ }^{1}$, Mateusz Przyborowski ${ }^{1}$, Waclaw Orczyk ${ }^{2}$ and \\ Anna Nadolska-Orczyk ${ }^{1 *}$
}

'Department of Functional Genomics, Plant Breeding and Acclimatization Institute (IHAR) - National Research Institute, Blonie, Poland, ${ }^{2}$ Department of Genetic Engineering, Plant Breeding and Acclimatization Institute (IHAR) - National Research Institute, Blonie, Poland

OPEN ACCESS

Edited by:

Agnieszka Ludwików, Adam Mickiewicz University

in Poznań, Poland

Reviewed by:

Ibrokhim Abdurakhmonov,

The Center of Genomics and Bioinformatics, Uzbekistan

Taras P. Pasternak

Albert Ludwigs University of Freiburg.

Germany

*Correspondence:

Anna Nadolska-Orczyk

a.orczyk@ihar.edu.pl

Specialty section:

This article was submitted to

Plant Biotechnology,

a section of the journal

Frontiers in Plant Science

Received: 11 October 2016 Accepted: 19 December 2016 Published: 09 January 2017

Citation:

Gasparis S, Kała M Przyborowski M, Orczyk W and Nadolska-Orczyk A (2017) Artificial MicroRNA-Based Specific Gene Silencing of Grain Hardness Genes

in Polyploid Cereals Appeared to Be

Not Stable Over Transgenic Plant Generations. Front. Plant Sci. 7:2017.

doi: 10.3389/fpls.2016.02017
Gene silencing by RNA interference is a particularly important tool in the study of gene function in polyploid cereal species for which the collections of natural or induced mutants are very limited. Previously we have been testing small interfering RNA-based approach of gene silencing in wheat and triticale. In this research, artificial microRNAs (amiRs) were studied in the same species and the same target genes to compare effectiveness of both gene silencing pathways. amiR cassettes were designed to silence Puroindoline a (Pina) and Puroindoline $b$ (Pinb) hardness genes in wheat and their orthologues Secaloindoline a (Sina) and Secaloindoline b (Sinb) genes in triticale. Each of the two cassettes contained $21 \mathrm{nt}$ microRNA ( $\mathrm{miR}$ ) precursor derived from conserved regions of Pina/Sina or Pinb/Sinb genes, respectively. Transgenic plants were obtained with high efficiency in two cultivars of wheat and one cultivar of triticale after using the Pinb-derived amiR vector for silencing of Pinb or Sinb, respectively. Lack of transgenic plants in wheat or very low transformation efficiency in triticale was observed using the Pina-derived amiR cassette, despite large numbers of embryos attempted. Silencing of Pinb in wheat and Sinb in triticale was highly efficient in the $T_{1}$ generation. The transcript level of Pinb in wheat was reduced up to $92 \%$ and Sinb in triticale was reduced up to 98\%. Moreover, intended silencing of Pinb/Sinb with Pinb-derived amiR cassette was highly correlated with simultaneous silencing of Pina/Sina in the same transgenic plants. High downregulation of Pinb/Pina genes in $T_{1}$ plants of wheat and Sinb/Sina genes in $T_{1}$ plants of triticale was associated with strong expression of Pinb-derived amiR. Silencing of the target genes correlated with increased grain hardness in both species. Total protein content in the grains of transgenic wheat was significantly lower. Although, the Pinb-derived amiR cassette was stably inherited in the $T_{2}$ generation of wheat and triticale the silencing effect including strongly decreased expression of silenced genes as well as strong expression of Pinb-derived amiR was not transmitted. Advantages and disadvantages of posttranscriptional silencing of target genes by means of amiR and siRNA-based approaches in polyploid cereals are discussed.

Keywords: polyploid cereals, amiRNA, siRNA, RNAi, wheat, triticale, grain hardness, Pin genes 


\section{INTRODUCTION}

Common wheat (Triticum aestivum L.) is the world's third, after corn and rice, major cereal crop and an important human food source (Tester and Langridge, 2010). Triticale ( $\mathrm{x}$ Triticosecale Wittmack) is a hybrid of wheat (Triticum) and rye (Secale) with higher yield potential and disease, and environmental tolerance but lower grain quality than wheat. In 2014, triticale was cultivated in 37 countries across the world (FAO Statistics Division, 2016). Genomes of these Triticeae species are allohexaploid, composed of three diploid genomes $(2 n=6 x=42)$, differing for one of them (AABBDD for wheat and AABBRR for triticale). The genome size, which is $17 \mathrm{Gbp}$ for wheat (Bennett and Smith, 1976), and its complexity in both species represent an important limitation in collecting mutants of many important traits and analysis of gene function.

Cereal grain hardness is an important agronomic trait that influences quality of the flour and properties of the end-products. The soft grain phenotype in wheat is determined by wild-type alleles of Pina and Pinb genes and any mutation in either or both Pin gene(s) results in more or less harder grains (reviewed in Bhave and Morris, 2008; Nadolska-Orczyk et al., 2009; Pauly et al., 2013). Consistent with the above is reported by Gasparis et al. (2011) increased grain hardness after siRNA-mediated silencing of the Pin genes. Sina and Sinb genes of hexaploid triticale are orthologs of Pin genes in hexaploid wheat. The influence of these genes on grain hardness in triticale is expected to be similar, however, this has not been confirmed (Gasparis et al., 2013).

Gene silencing by RNA interference (RNAi) is a powerful technology of reverse genetics to characterize gene function and to obtain plants with desired characteristics, i.e., enhancing crop yield/productivity, quality and resistance to biotic and abiotic stresses. The technology is based on the natural processes of regulation of gene expression by small RNAs (sRNAs) including microRNAs (miRNAs) and short interfering RNAs (siRNAs) (Ossowski et al., 2008; Axtell, 2013; Rogers and Chen, 2013). These sRNAs, mostly 21-24 nt in length, direct sequence-specific gene regulation originally induced by double stranded RNA (dsRNA), resulting in inhibition of transcription or translation (Hamilton and Baulcombe, 1999; Brodersen and Voinnet, 2006; Borges and Martienssen, 2015). Gene silencing by siRNA, termed in plants as post-transcriptional gene silencing (PTGS; van der Krol et al., 1990) has been widely used since the late 1990s (Waterhouse and Helliwell, 2003; Baulcombe, 2004). The technology became a method of choice for analysis of gene function, especially in polyploid species (Lawrence and Pikaard, 2003; Travella et al., 2006; reviewed by $\mathrm{Fu}$ et al., 2007; Gasparis et al., 2011, 2013). The resulted phenotypes were found to be stable inherited through generations.

microRNAs are key regulators of important plant processes, such as growth, development, and response to various stresses (Martin et al., 2010; Ameres and Zamore, 2013). In wheat miRNAs and their targets play a complex role in regulation of grain development (Li et al., 2015). These sRNAs in plants were identified in 2002 by different groups (Llave et al., 2002; Mette et al., 2002; Park et al., 2002; Reinhart et al., 2002). miRNA differs from siRNA in their precursor structures, origin and biogenesis, modes of action, and cellular and developmental functions (Carthew and Sontheimer, 2009; Ghildiyal and Zamore, 2009; Axtell, 2013; Kamthan et al., 2015). The natural mechanism of gene regulation by miRNA was used as base to design experimental tool termed artificial microRNA (amiR) (Ossowski et al., 2008; Tiwari et al., 2014) or miRNA-induced gene silencing (MIGS) (Felippes et al., 2012). In contrast to siRNAs, miRNAs are produced from long, single-stranded RNA molecules exhibiting highly specific stem-loop structures (Chen, 2009). Silencing cassettes of amiRNA are designed by replacing the mature $21 \mathrm{nt}$ miRNA sequences within pre-miRNA with $21 \mathrm{nt}$ long fragment derived from the target gene. Integrated with the genome amiRNA is expressed and the resultant transcript is subsequently processed via small RNA biogenesis. Finally, the active amiRNA molecule triggers silencing of the target gene in a manner similar to miRNAs. amiRNA-based strategies are regarded to be more efficient due to their higher specificity and fewer undesirable off-target effects (Schwab et al., 2006; Meyers et al., 2008; Warthmann et al., 2008) compared to siRNA (Xu et al., 2006). Artificial miRNA was applied to silence diverse groups of genes in different species (Alvarez et al., 2006; reviewed by Tiwari et al., 2014 and Kamthan et al., 2015). Similar to miRNAs, amiRNAs might regulate gene expression at the transcriptional (TGS) or posttranscriptional level.

There are several reports on gene silencing by amiRNA in monocot species. Silencing of endogenous genes in rice was successful, with amiRNAs having been expressed in the OsMIR528 precursor (Warthmann et al., 2008; Butardo et al., 2011; Chen et al., 2012). In wheat, there is only one article on using amiRNA approach to obtain plants resistant to Wheat streak mosaic virus (WSMV) (Fahim et al., 2012). The strategy was to incorporate five amiRNAs within one polycistronic amiRNA precursor. Resistance was assessed over two generations. The same polycistronic type of vector, which was based on a barley miRNA precursor backbone and targeted different conservative sequences of Wheat dwarf virus (WDV), conferred barley resistance to the virus at low temperature (Kis et al., 2016). Recent research indicated that synthetic/artificial trans-acting siRNAs (syn-tasiRNAs) carrying multiple virus resistance cassettes might be more effective than amiRNA for enhanced antiviral defense (Carbonell et al., 2016; Chen et al., 2016).

In our previous research, we have tested silencing of Pina and Pinb hardness genes in wheat (Gasparis et al., 2011) and their orthologs, Sina and Sinb genes in triticale (Gasparis et al., 2013) by siRNA strategy, using the hairpin type of cassette. The transcript level of the genes was reduced by over $80 \%$ in $\mathrm{T}_{1}$, and over $90 \%$ in $\mathrm{T}_{2}$ up to $\mathrm{T}_{4}$, and was stable through generations. Moreover, this RNA-mediated silencing of one of the Pin or Sin genes simultaneously decreased the expression of the second Pin or Sin. The reduction of transcript levels of both genes resulted in a significant decrease or lack of both puroindoline and secaloindoline proteins and increased grain hardness in wheat. In contrast to the results obtained 
with the Pin genes, the decreased expression of Sin genes and lower level of secaloindoline proteins did not affect grain hardness.

In this research, we applied artificial miRNA to silence Pina/Sina and Pinb/Sinb grain hardness genes of two hexaploid Triticeae species, wheat and triticale, and to compare the effect of silencing with siRNA in the PTGS pathway. The same research model, i.e., grain hardness genes, and the same cultivars of two polyploid cereal species were used. amiRNAs were designed based on conserved precursor miRNA of wheat, Tae-miR164. The very high expression of Pinb-derived amiR in the $\mathrm{T}_{1}$ generation resulted in strongly decreased expression of Pinb and Sinb genes in both species, which was correlated with reduced protein level and significantly increased grain hardness. The silencing of one Pinb or Sinb gene simultaneously influenced silencing of their corresponding paralogue Pina or Sina. While Pinbderived amiR silencing cassette was stably inherited, the strong effect of silencing was not transmitted to the $\mathrm{T}_{2}$ generation and Pinb-derived amiR was not expressed in both species. To our knowledge, this is the first report on the effect of silencing by amiRNAs of a structural, endogenous genes in polyploid cereals implicating a non-inherited mode of silencing.

\section{MATERIALS AND METHODS}

\section{Plant Material}

Two cultivars of Polish spring wheat, Kontesa, and Torka (Triticum aestivum $\mathrm{L}$ ), and one cultivar of spring triticale, Wanad (x Triticosecale Wittmack), were used in the experiments. Wild type, donor plants for transformation experiments as well as transgenic plants were grown under controlled conditions of long day (16 h light) as described by Gasparis et al. (2013).

\section{AmiRNA Design and Cloning, and Vector Construction}

Artificial microRNA cassettes for silencing Pina and Pinb genes in wheat, and Sina and Sinb genes in triticale, were constructed based on precursor microRNA of wheat TaemiR164 (Mirbase.org: MI0006173). Primers for amplification and sequencing of precursor Tae-miR164 were designed based on the EST sequence (access number CA704421). The sequences of the primers were: forward 5'-AGGTGGAGAAGCAGGGCACGT-3' and reverse $5^{\prime}$ - TATCACGCAGAGCTGACACCACAA-3'. The primers were used to amplify specific precursor Tae-miR164 in Kontesa and Torka cultivars. In the next step, native fragments of microRNA of $21 \mathrm{bp}$ in precursor Tae-miR164 were replaced with the sequence complementary to the Pin and Sin genes. The $21 \mathrm{bp}$ sequences of microRNA for these genes were designed based on the Web MicroRNA Designer platform (WMD3 ${ }^{1}$ ) (Ossowski et al., 2008). The sequences were: (1) for Pinaderived amiR (ami-Pa): 5'-UGAAAUCCGAAGAUGCCATCG$3^{\prime}$ complementary to the sequence of allele Pina-D1a in the region of 321-341 and (2) for Pinb-derived amiR (ami-Pb): 5'-UGUUUGAAUACCUCACCUAGC-3' complementary to the

${ }^{1}$ http://wmd3.weigelworld.org sequence of allele Pinb-D1c in the region of 348-368. Precursor microRNA was cloned into the pGEM-T (Promega) vector and used as a template for multiple PCR amplification to insert designed amiRNA into the precursor. Primers used in these reactions are as follows:

(a) Primers for ami-Pa amplification:

1. ami_pa1 5'-ggTGAAATCCGAAGATGCCATCGttca tttccaggtcgct- $3^{\prime}$

2. ami_pa2 $5^{\prime}$-aaCGATGGCATCTTCGGATTTCAccaat ccogcggccatg- $3^{\prime}$

3. ami_pa3 5'-caCGCTGGCATCTTCGGATTTCAccaat cactagtgcggc- $3^{\prime}$

4. ami_pa4 5' -ggTGAAATCCGAAGATGCCAGCGtgcat gggecggctgec $-3^{\prime}$

pgt_A $5^{\prime}$-actcactatagggcgaattg- $3^{\prime}$

pgt_B $5^{\prime}$-actcaagctatgcatccaac- $3^{\prime}$

(b) Primers for ami-Pb amplification:

1. ami_pb1 5'-ggTGTTTGAATACCTCACCTAGCttcat ttccaggtcgct- $3^{\prime}$

2. ami_pb2 5'-aaGCTAGGTGAGGTATTCAAACAccaat cccgcggccatg- $3^{\prime}$

3. ami_pb3 5'-caGCCAGGTGAGGTATTCAAACAccaat cactagtgcggc- $3^{\prime}$

4. ami_pb4 5' -ggTGTTTGAATACCTCACCTGGCtgcat gggecggctgcc- $3^{\prime}$ pgt_A $5^{\prime}$ - actcactatagggcgaattg- $3^{\prime}$ pgt_B $5^{\prime}$-actcaagctatgcatccaac- $3^{\prime}$

The order of the amplification procedure was: (1) pgt_A and ami_pa2 primers; (2) ami_pa3 and pgt_B primers; (3) ami_pa1 and ami_pa4 primers, and (4) products of amplification from 1 to 3 reactions plus pgt_A, pgt_B primers.

The cassettes containing ami-Pa and ami-Pb were cloned into the pBract214 overexpression vector ${ }^{2}$. The vector is compatible with the Gateway cloning system. In the first step, the cassettes were amplified using: ami_pa5 5'-GGTGAAATCC GAAGATGCCATCGTT-3', ami_pa6 5'-GATTGGTGAAAT CCGAA-3', and ami_pb5 with: 5'-GGTGTTTGAATACCTCAC CTAGCTT-3', ami_pb6 5'-GATTGGTGTTTGAATAC-3', respectively and cloned into the entry vector pCR8/GW/TOPO (Invitrogen). In the next step, the cassettes were cloned to the destination pBract214 vector in the Gateway reaction. The presence of the amiRNA in the vectors was verified by restriction analysis and sequencing. The vectors were electroporated into the AGL1 strain of Agrobacterium tumefaciens and used for transformation.

\section{Agrobacterium-Mediated Transformation and PCR Testing}

Agrobacterium-mediated transformation experiments were performed according to our previously described protocols for wheat (Przetakiewicz et al., 2003, 2004) and for triticale (Nadolska-Orczyk et al., 2005). Putative transgenic plants were

${ }^{2}$ https://www.jic.ac.uk/technologies/crop-transformation-bract/ 
regenerated and selected on modified MS media containing $20 \mathrm{mg} \mathrm{l}^{-1}$ of hygromycin as a selectable agent.

Genomic DNA was isolated from young leaves of 5 days seedlings according to the modified CTAB procedure (Murray and Thompson, 1980). The PCR was carried out in a $25 \mu \mathrm{l}$ reaction mixture using Platinum Taq DNA Polymerase (Invitrogen) and $120 \mathrm{ng}$ of template DNA. The reaction was run using the following program: initial denaturation step at $94^{\circ} \mathrm{C}$ for $2 \mathrm{~min}, 35$ cycles of amplification at $94^{\circ} \mathrm{C}$ for $30 \mathrm{~s}, 65^{\circ} \mathrm{C}$ for $30 \mathrm{~s}$, $72^{\circ} \mathrm{C}$ for $30 \mathrm{~s}$ with a final extension step at $72^{\circ} \mathrm{C}$ for $5 \mathrm{~min}$.

The wheat and triticale plants transformed with Pina-derived amiR and Pinb-derived amiR vectors were tested with two pairs of specific primers amplifying a fragment of the $h p t$ selection gene. The sequences of the primers for the first pair were: $\mathrm{pBr}$.hygF2 5'-GACGGCAATTTCGATGATG-3' and pBr_hyg-R2 5'CCGGTCGGCATCTACTCTAT- ${ }^{\prime}$, and amplified fragment of $205 \mathrm{bp}$. The sequences of the primers for the second pair were: pBr_hygF4 5'-ATGACGCACAATCCCACTATCCT-3' and pBr_hygR4 5'-AGTTCGGTTTCAGGCAGGTCTT-3', and amplified fragment of $405 \mathrm{bp}$.

Putative transgenic $\mathrm{T}_{0}$ plants were tested with each of the two pairs of specific primers. In case if one PCR test was positive and the second one was negative the third one was applied with one of these two pairs of primers. Only PCR positive (PCR + ) plants were grown for further testing. The same PCR tests were applied for eight randomly selected $\mathrm{T}_{2}$ progeny from one $\mathrm{T}_{1}$ transgenic parent. Segregation rates were estimated based on PCR $+/ P C R-$ plants. Non-transgenic, in vitro plants as well as null segregants were used as a control.

\section{RNA Isolation and cDNA Synthesis}

Total RNA was isolated from immature kernels at 26 DAP (days after pollination) using the modified SDS extraction method of Prescott and Martin (1986). An additional extraction step was performed using TRI-Reagent (Sigma-Aldrich) according to the manufacturer's protocol. The RNA samples were digested with DNAse I recombinant (Roche). The first-strand cDNA was synthesized from $1 \mu \mathrm{g}$ of RNA using the RevertAid First Strand cDNA Synthesis Kit (Thermo Scientific) according to the manufacturer's instructions.

\section{Quantitative Real-Time qRT-PCR}

The relative expression level of Pin genes in wheat and Sin genes in triticale was analyzed in 26 DAP samples of transgenic and control plants. The sequences of the primers were as follows: for Pina and Sina, qPinA1 (forward) $5^{\prime}$-CTCA TAGGACTGCTTGCTCTGGTAG-3', qPinA2 (reverse) 5'-GAT TGACCCCTGGATGATGTTG-3'; for Pinb and Sinb, qPinB1 (forward) 5'-AATGAAGTTGGCGGAGGAGGTG-3', qPinB2 (reverse) $5^{\prime}$-ATACCTCACCTCGCCAAATGCC-3'; and for $18 \mathrm{~S}$ rRNA, 18S F (forward) 5'-GTGACGGGTGACGGAGAATT3', 18S R (reverse) 5'-GACACTAATGCGCCCGGTAT-3'. The reaction was carried out in a $15 \mu \mathrm{l}$ mixture containing $1 \times$ Hot FIREPol EvaGreen qPCR Mix (Solis BioDyne), $0.4 \mu \mathrm{M}$ of each primer, and $1 \mu \mathrm{l}$ of the template cDNA. The following temperature profile was used: an initial denaturation step of $95^{\circ} \mathrm{C}$ for $15 \mathrm{~min}, 50$ cycles of amplification at $95^{\circ} \mathrm{C}$ for $20 \mathrm{~s}, 58^{\circ} \mathrm{C}$ for $15 \mathrm{~s}$, and $72^{\circ} \mathrm{C}$ for $20 \mathrm{~s}$, and a melting curve profile of $72-$ $95^{\circ} \mathrm{C}$ with the temperature rising $1^{\circ} \mathrm{C}$ at each step and continuous fluorescence measurement. Three replicates of each sample were used in the reaction. The relative expression level of Pin and Sin genes was calculated by the standard curve method using $18 \mathrm{~S}$ rRNA as a normalizer. The non-transgenic control plant was used as a calibrator sample with the expression level set to 1 . The normalized values of the tested samples are expressed as $\mathrm{x}$-fold of 1 .

\section{Identification of amiRNA in Transgenic Plants}

Low molecular weight RNA containing the microRNA fraction was separated from total RNA using polyethylene glycol (PEG) as described by Goto et al. (2003). The artificial Pinb-derived miR was detected by stem-loop RT-PCR miRNA assay as described by Varkonyi-Gasic et al. (2007). Two hundred and fifty nanograms of RNA from each sample and $0.05 \mu \mathrm{M}$ of RT primer were used for the reverse transcription reaction with Maxima reverse transcriptase (Thermo Scientific). The loop region of RT primers contained a sequence complementary to UPL probe \#21 (highlighted in bold). Primers for endogenous Tae-miR164 were used in the positive control sample. The sequences for RT and qPCR primers were: for ami-Pb: RT primer 5'-GTTGGCTCTGGTGCAGGGTCCGAGGTATTCGCACCAG AGCCAACGCTAGG-3' and forward primer $5^{\prime}$ - GGTGTTTGA ATACCTCACCTAGC $-3^{\prime}$ and reverse primer $5^{\prime}$-GTGCAGGG TCCGAGGT-3'; for Tae-miR164: RT primer 5'-GTTGGCTC TGGTGCAGGGTCCGAGGTATTCGCACCAGAGCCAACTG CACG-3', forward primer 5'-TGGAGAAGCAGGGCACGT GCA- $3^{\prime}$ and reverse primer $5^{\prime}$-GTGCAGGGTCCGAGGT-3'; and for U6 RNA: forward primer $5^{\prime}$-CTTCGGGGACATCCGA TAAA- $3^{\prime}$ and reverse primer $5^{\prime}$-GACCATTTCTCGATTTGT GC-3'.

Samples were first incubated at $65^{\circ} \mathrm{C}$ for $5 \mathrm{~min}$, and the reverse transcription reaction was performed using the following program: $94^{\circ} \mathrm{C}$ for $2 \mathrm{~min}$ followed by 40 cycles of $94^{\circ} \mathrm{C}$ for $15 \mathrm{~s}$ and $60^{\circ} \mathrm{C}$ for $1 \mathrm{~min}$. The qPCR reaction was carried out in a $20 \mu \mathrm{l}$ reaction mixture containing $10 \mu \mathrm{l}$ of TaqMan Fast Advanced Master Mix (Applied Biosystems), $2 \mu \mathrm{l}$ of cDNA sample, $0.4 \mu \mathrm{M}$ of each primer and $0.25 \mu \mathrm{l}$ of UPL probe \#21 (Roche). The reaction was run in a RotorGene $\mathrm{Q}$ thermal cycler (Qiagen) using the following program: initial denaturation step at $95^{\circ} \mathrm{C}$ for $2 \mathrm{~min}$ followed by 55 cycles of amplification at $95^{\circ} \mathrm{C}$ for $5 \mathrm{~s}, 60^{\circ} \mathrm{C}$ for $15 \mathrm{~s}$, and $72^{\circ} \mathrm{C}$ for $5 \mathrm{~s}$. U6 RNA was used as a reference gene. A series of dilutions of amplified amiRNA and U6 RNA was used in the first qPCR reaction to estimate the reaction efficiency. The relative level of amiRNA was calculated using the Pfaffl method (Pfaffl, 2001). The sample with the highest Ct value was used as a calibrator. The level of amiR was determined as $\mathrm{x}$-fold higher compared to the calibrator sample, which was the sample with the lowest detectable amiR level set to 1.0.

\section{Extraction of Proteins and SDS-PAGE}

Friabilin (complex of puroindoline $a$ and puroindoline $b$ ) was extracted from the surfaces of the starch granules using the 
method of Bettge et al. (1995) with some modifications. To obtain $50 \mathrm{mg}$ of wheat flour, 100-150 mg of kernels were ground in a mortar. After being transferred to a $2 \mathrm{ml}$ microfuge tube containing $0.6 \mathrm{ml}$ of $0.1 \mathrm{M} \mathrm{NaCl}$, the samples were incubated at room temperature for $30 \mathrm{~min}$ in a thermoshaker. The aqueous starch suspension was transferred to a new $2 \mathrm{ml}$ microfuge tube and centrifuged at $15000 \times g$ for $1 \mathrm{~min}$. The pellet was washed with $1 \mathrm{ml}$ of water. Using a pipette tip, the gluten and bran residues were formed into a ball and removed. The starch pellet was resuspended in $1 \mathrm{ml}$ of $80 \% \mathrm{CsCl}$ and centrifuged at $15000 \times g$ for $1 \mathrm{~min}$. The $\mathrm{CsCl}$ solution was then removed from the tube, and the sample was washed three times with $1 \mathrm{ml}$ of water and once with $0.6 \mathrm{ml}$ of acetone. The pellet was left to dry and the tubes were weighed to determine the amount of starch. Next, the starch pellets were suspended in $150 \mu \mathrm{l}$ of $1 \mathrm{M} \mathrm{NaCl}$ and $150 \mu \mathrm{l}$ of isopropanol. After incubation for $45 \mathrm{~min}$ at $45^{\circ} \mathrm{C}$, the samples were centrifuged at $15000 \times g$ for $1 \mathrm{~min}$. The supernatant was transferred to fresh microfuge tubes and $150 \mu \mathrm{l}$ of cold acetone was added, and samples were stored overnight at $-20^{\circ} \mathrm{C}$. Next, the samples were centrifuged at $15000 \times g$ for $1 \mathrm{~min}$ and transferred to fresh microfuge tubes. This fraction was precipitated for $2 \mathrm{~h}$ with $1 \mathrm{ml}$ of cold acetone at $-20^{\circ} \mathrm{C}$ and centrifuged at $15000 \times g$ for $10 \mathrm{~min}$. The resulting protein pellet was resuspended in $30 \mu \mathrm{l}$ of water, $3 \mu \mathrm{l}$ of BME and $30 \mu \mathrm{l}$ of SDS-PAGE sample buffer (Laemmli, 1970), mixed, and incubated at $70^{\circ} \mathrm{C}$ for $10 \mathrm{~min}$.

The SDS-PAGE buffers and gels were prepared according to Laemmli (1970). The stacking gels were 5\% T, 2.6\% C, and the resolving gels were $15 \% \mathrm{~T}, 2.6 \% \mathrm{C} 1.5 \mathrm{~mm}$ thick. $18 \mathrm{~cm} \times 16 \mathrm{~cm}$ gels were run in Hoeffer SE 660 apparatus at $20 \mathrm{~mA}$ until the dye reached the bottom edge of the gel. After electrophoresis, the gels were silver stained using the procedure of Gromova and Celis (2006).

\section{SKCS and Total Protein Analysis}

The grain hardness, weight, moisture, and diameter of 50 kernels were measured using the Single Kernel Characterization System (SKCS) 4100 (Perten Instruments) for each individual kernel.

The total grain protein content was determined by the Dumas method (Dumas, 1831). The samples of $250 \mathrm{mg}$ of ground seeds in three replicates were combusted at $960^{\circ} \mathrm{C}$ in the presence of oxygen, followed by afterburning at $800^{\circ} \mathrm{C}$, and dried with $\mathrm{P}_{2} \mathrm{O}_{5}$. The resultant nitrogen oxide was reduced to nitrogen. The content of nitrogen in the probes was recounted for crude protein using Rapid $\mathrm{N}$ Cube (Elementar, Germany). The formula $N \times 6.25$ was applied.

\section{Statistical Analysis}

Statistical analysis was performed using MS Excel and R studio ${ }^{3}$. Obtained data were analyzed by Pearson correlation or one way analysis of variance. Samples that did not meet the ANOVA assumptions were tested by Kruskal-Wallis test.

\footnotetext{
${ }^{3}$ https://www.rstudio.com/
}

\section{RESULTS}

\section{Artificial microRNA Cassette Specification}

Artificial microRNA for silencing of Pina or Sina genes (Pinaderived amiR) and Pinb or Sinb genes (Pinb-derived amiR) was constructed on the base on precursor miRNA of wheat Tae-miR164 (Mirbase.org: MI0006173) (Figure 1A). The final sequence of Pina-derived amiR and Pinb-derived amiR cassettes with the highlighted $21 \mathrm{nt}$ precursors is presented in Figure 1B. These specific precursors matched the Pina and Pinb or Sina and Sinb sequences as shown in Figure 1C.

\section{Transformation Efficiency Is Dependent on the amiR Sequence}

Potentially transgenic plants were selected on hygromycin. The transgenic character of these plants was proven by PCR amplification of T-DNA with two pairs of specific primers.

Transgenic plants were obtained after transformation of two cultivars of wheat (cv. Kontesa and cv. Torka) with the Pinbderived amiR vector. Transformation efficiency was 2.97 and $0.09 \%$, respectively (Table 1 ). In contrast, failure to obtain Pina-derived amiR transformed plants after inoculation of 2753 immature embryos of three cultivars of wheat in six experiments was observed.

Similar results were obtained for triticale cv. Wanad. Transformation efficiency was high $(3.78 \% ; \pm 0.32)$ with the Pinbderived amiR cassette and very low $(0.07 \%$; $\pm 0.04 \%)$ with the Pina-derived amiR cassette after inoculation of 4287 immature embryos in five independent experiments.

\section{Silencing of Pinb and Sinb Genes by Pinb-Derived amiR Is Highly Efficient in $\mathrm{T}_{1}$ Generation and Triggers Simultaneous Silencing of Pina/Sina}

Segregation ratio of PCR positive (PCR+) to PCR negative (PCR-) plants in $17 \mathrm{~T}_{1}$ lines of wheat and $12 \mathrm{~T}_{1}$ lines of triticale indicated that $2 / 3$ of these lines were one-locus transgenics and the remaining $1 / 3$ were two-loci transgenics. Relative expression of both Pina and Pinb or Sina and Sinb in 21 DAP kernels silenced with Pinb-derived amiR was estimated in 42 transgenic $\mathrm{T}_{1}$ plants from $13 \mathrm{~T}_{0}$ lines of wheat $\mathrm{cv}$. Kontesa and 18 transgenic $\mathrm{T}_{1}$ plants from $12 \mathrm{~T}_{0}$ lines of triticale cv. Wanad (Figures 2A,B). Ten of 13 tested wheat lines were one-locus and three lines were twoloci transgenics. In case of triticale 10 lines were one-locus and two lines were two-loci transgenics. Relative expression of Pinb in $\mathrm{T}_{1}$ wheat plants, ranging from 0.06 up to 1.59 , was below 0.2 in 11 plants (26\%) from seven lines and between 0.2 to 0.5 in 20 plants (48\%) from 10 lines. All plants with relative expression equal or lower then 0.8 compared to control set to $1.0( \pm 0.19)$ are considered as "silenced," while relative expression over 1.2 indicated overexpression.

Similar results of downregulation in the Pinb-derived amiR transgenic plants were obtained for the second, Pina gene. The same 31 (74\%) of $\mathrm{T}_{1}$ plants showing relative Pinb silencing below 
A

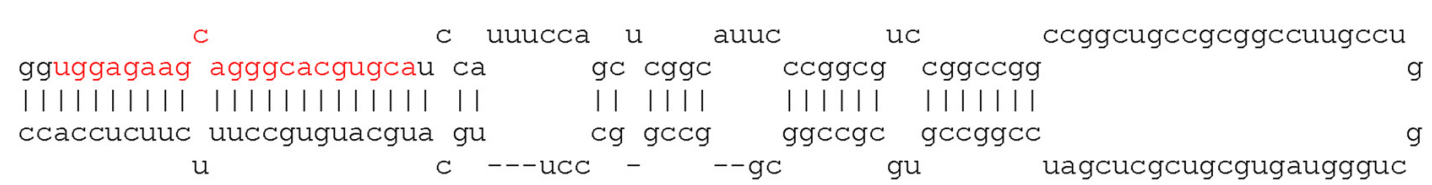

B

amiRNA Pina/Sina: GGTGAAATCCGAAGATGCCATCGTTCATTTCCAGGTCGCTTCCCGGCGTCCGGCCGGCACGCACCGCCG CGGCGGCCTTGCTTGGTCAGTGTGTCGCTCGATCCGGCCGTGCGCCGGCAGCCGGCCCATGCACGCTGG CATCTTCGGATTTCACC amiRNA Pinb/Sinb: GGTGTTTGAATACCTCACCTAGCTTCATTTCCAGGTCGCTTCCCGGCGTCCGGCCGGCACGCACCGCCG CGGCGGCCTTGCTTGGTCAGTGTGTCGCTCGATCCGGCCGTGCGCCGGCAGCCGGCCCATGCAGCCAG GTGAGGTATTCAAACACC

C

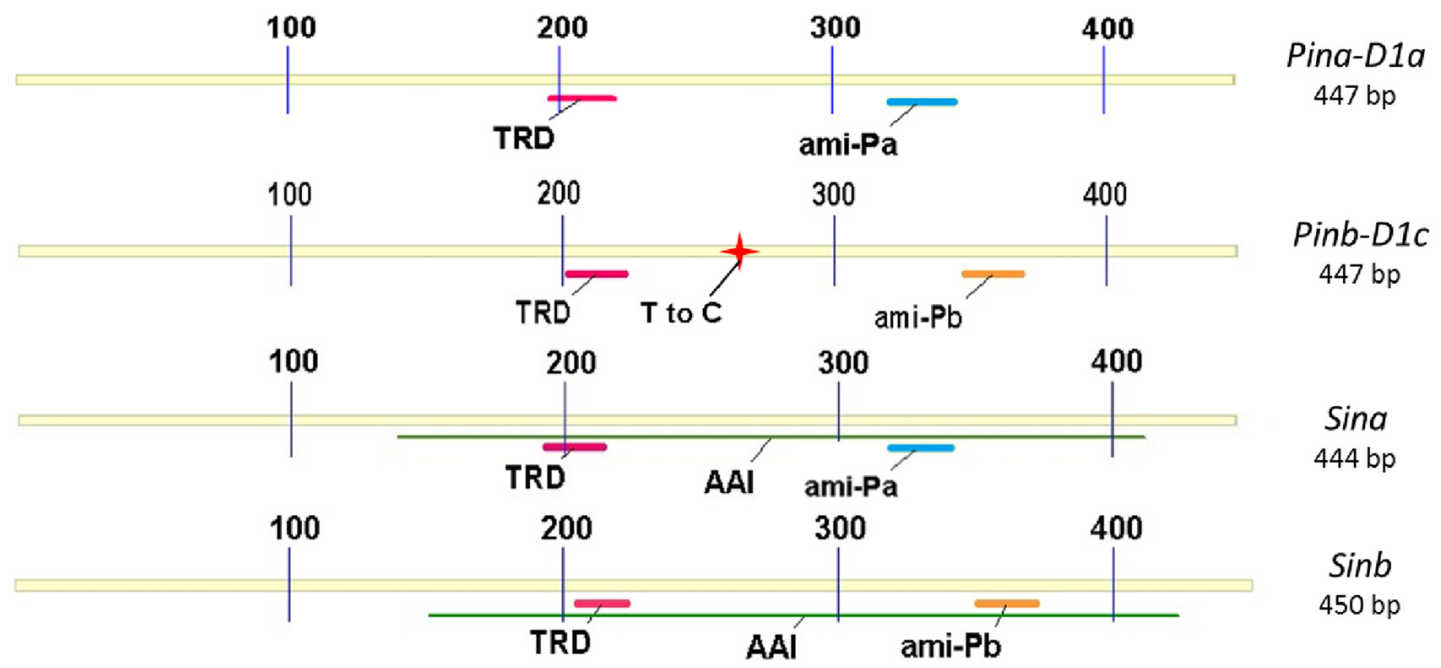

FIGURE 1 | Construction of artificial miRNA for silencing of Pin and Sin genes and schematic diagram of Pin and Sin coding sequences. Secondary structure of the wild type of the Tae-miR164 precursor (A). Sequence of the modified precursor (B). Schematic diagram of silenced genes with important domains and matching Pina-derived and Pinb-derived amiR fragments (C). TRD, tryptophan rich domain; AAl, alpha-amylase inhibitor; T to C, thymine to cytosine transition at position 266 (leucine to proline change in position 60 of Pinb-D1c allele compared to wild Pinb-D1a).

TABLE 1 | Transformation efficiency of wheat and triticale cultivars with Pina-derived amiR (ami-Pa) and Pinb-derived amiR (ami-Pb) vectors.

\begin{tabular}{|c|c|c|c|c|c|c|}
\hline Cultivar/species & $\begin{array}{c}\text { Vector } \\
\text { pBract214 }\end{array}$ & $\begin{array}{c}\text { Number of transformation } \\
\text { experiments }\end{array}$ & $\begin{array}{l}\text { Number of } \\
\text { explants }\end{array}$ & $\begin{array}{l}\text { Number of } \\
\text { lines }\end{array}$ & $\begin{array}{l}\text { Number of } \\
\text { plants }\end{array}$ & $\begin{array}{l}\text { Transformation } \\
\text { efficiency (\%) (SE) }\end{array}$ \\
\hline \multicolumn{7}{|c|}{ Wheat } \\
\hline & $\mathrm{ami}-\mathrm{Pb}$ & 1 & 640 & 19 & 28 & $2.97(*)$ \\
\hline Torka & ami-Pa & 1 & 411 & 0 & 0 & $0.00(*)$ \\
\hline \multicolumn{7}{|c|}{ Triticale } \\
\hline \multirow[t]{2}{*}{ Wanad } & ami-Pa & 5 & 4287 & 3 & 3 & $0.07(0.04)$ \\
\hline & ami-Pb & 2 & 1033 & 39 & 54 & $3.78(0.32)$ \\
\hline
\end{tabular}

*, not applicable; SE, standard error. 

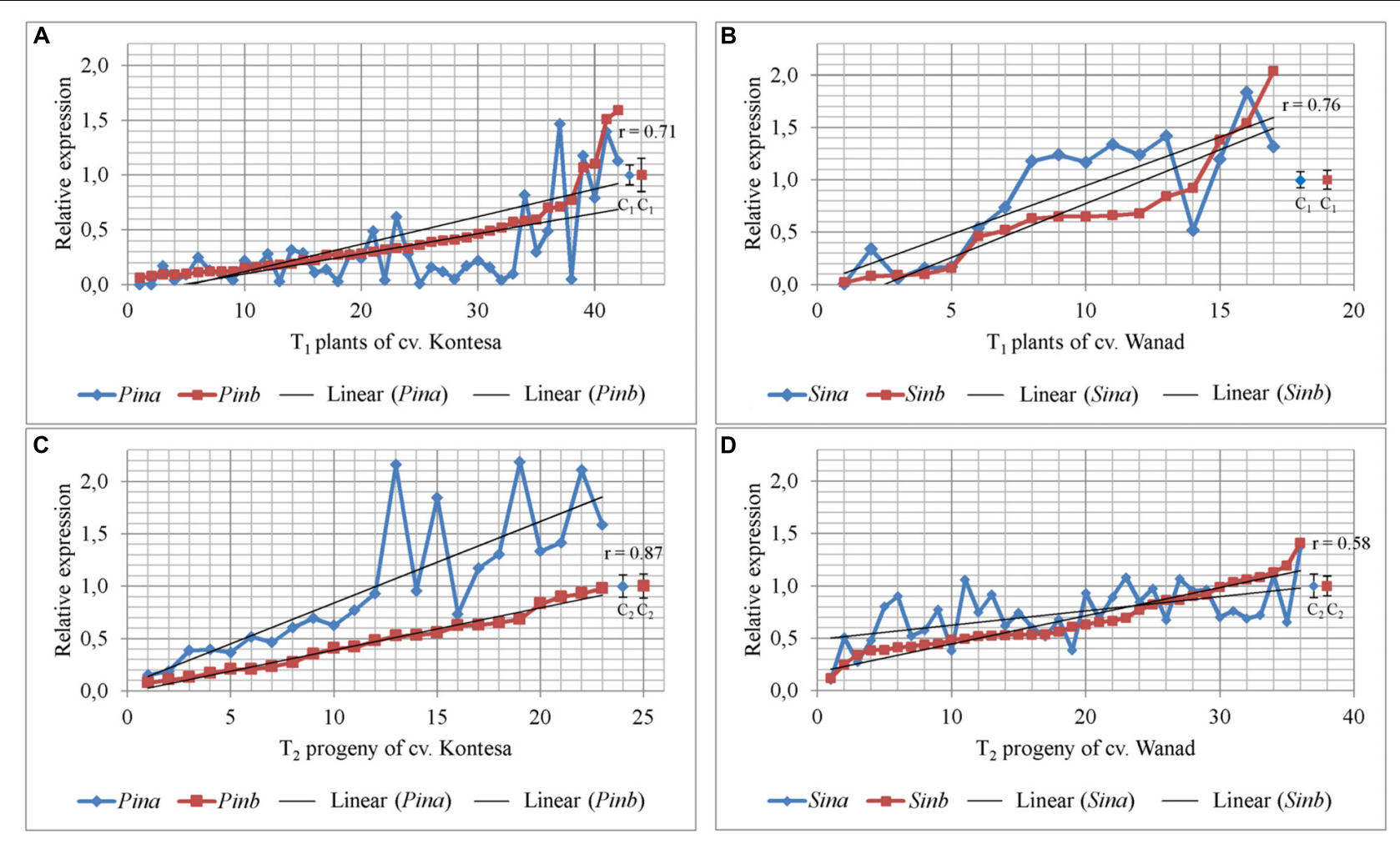

FIGURE 2 | Relative expression of Pin and Sin genes in 26 DAP kernels of $T_{1}$ transgenics and their $T_{2}$ progeny silenced with Pina-derived and Pinb-derived amiR constructs. Values for Pina and Pinb genes in $T_{1}$ silenced plants (A) and $T_{2}$ progeny (C) of wheat cv. Kontesa. Relative expression of Sina and Sinb genes in $T_{1}$ silenced plants (B) and $T_{2}$ progeny (D) of triticale cv. Wanad. C, control lines; $r=$ positive and significantly important $(\alpha=0.01)$ correlation between Pina and Pinb, and Sina and Sinb.

0.5 also showed Pina silencing at a corresponding or even lower level (Figure 2A). The correlation coefficient between silencing of Pinb and Pina in $\mathrm{T}_{1}$ wheat Pinb-derived amiR transgenics was high and statistically significant $(\rho=0.71 ; \alpha=0.01)$.

These data of Pinb (and Pina) gene(s) silencing correlated with expression of amiR specific to the Pinb gene. The level of Pinb-derived amiR in seven plants with strong silencing of both Pina and Pinb was from $0.3 \times 10^{6}$ to $68 \times 10^{6}$ fold higher compared to the calibrator sample (i.e., the sample with the lowest detectable amiR level set to 1.0). In another set of seven plants with weaker silencing the values, ranging between $3 \times 10^{2}$ and $7 \times 10^{2}$, were from three to five orders of magnitude lower. The highest level of expression of amiR was found in one-locus transgenic plants and lower level was in two-loci plants.

Relative expression of Sinb in $\mathrm{T}_{1}$ triticale plants ranged from 0.02 up to 2.04 (Figure 2B). Five of them showed very low expression of Sinb, below 0.2, with a corresponding low expression of Sina. Relative expression of Sinb for half of the $\mathrm{T}_{1}$ triticale plants ranged from 0.46 to 0.92 , but the corresponding Sina expression for most of them was above 1.0. Correlation between the expression of Sinb and Sina in $\mathrm{T}_{1}$ was statistically significant $(r=0.76 ; \alpha=0.01)$. The expression of Pinb and Pina, and Sinb and Sina, was not decreased in very few $\mathrm{T}_{1}$ plants of both Triticeae species.

\section{The Strong Effect of Silencing of Pin and Sin Genes in the $\mathrm{T}_{1}$ Is Not Transmitted to the $T_{2}$ Generation}

The transgenic character of all tested $\mathrm{T}_{2}$ plants was proved by PCR analysis with specific primers. Relative expression of Pinb in $\mathrm{T}_{2}$ progeny of wheat $\mathrm{cv}$. Kontesa ranged from 0.08 to 0.98 and for Pina from 0.15 to 2.16 (Figure 2C). About half of the plants out of 23 tested showed relative Pinb expression below 0.5. The Pina expression in the same plants was considerably higher. Relative expression for Pina in plants with $0.5-1.0$ values of Pinb silencing was very unstable and in most of the progeny ranged from 1.0 to 2.2. The correlation between Pinb and Pina expression in $\mathrm{T}_{2}$ (Figure 2C) was strong, positive, and statistically significant $(r=0.81 ; \alpha=0.01)$.

The relative expression of both genes silent in eight tested $T_{1}$ plants of wheat was much higher in their $\mathrm{T}_{2}$ progeny comparing to $\mathrm{T}_{1}$ (Figure 3A). The significance of difference was confirmed by Kruskall-Wallis test $(p=2.41 \mathrm{e}-05, \alpha=0.05)$. The mean expression value for Pinb in $\mathrm{T}_{1}$ plants was $0.26( \pm 0.07)$ and for Pina was $0.21( \pm 0.04)$. The mean values for both Pinb and Pina genes in $\mathrm{T}_{2}$ progeny were respectively $0.48( \pm 0.07)$ and $0.87( \pm 0.12)$. The values in the $\mathrm{T}_{2}$ progeny were higher and more variable for Pina compared to the silenced Pinb. The mean relative expression for Pinb in $\mathrm{T}_{2}$ was higher in individual lines as 

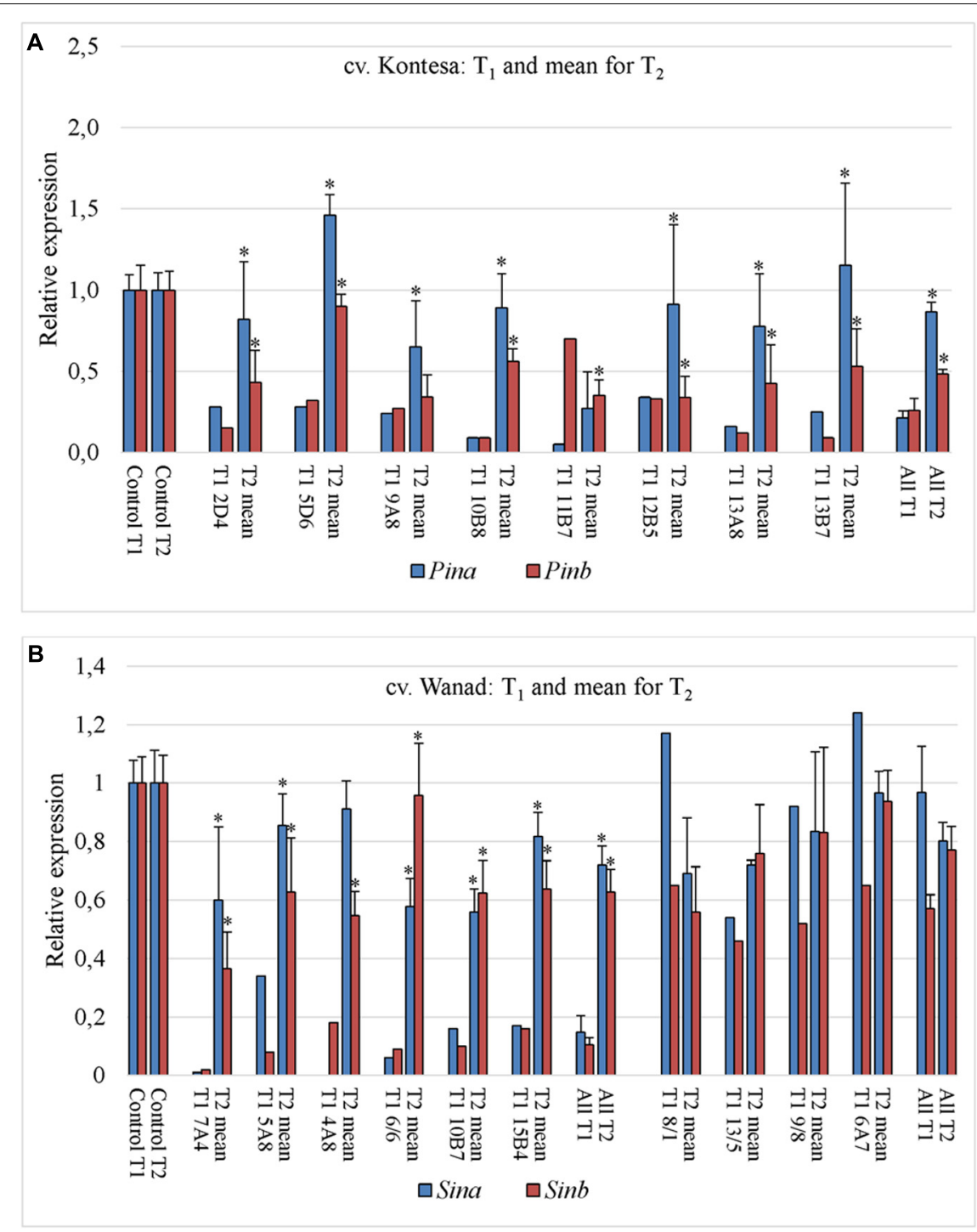

FIGURE 3 | Transmission of silencing effect from $\mathbf{T}_{\mathbf{1}}$ to $\mathbf{T}_{\mathbf{2}}$ generation in two polyploid cereal species. Relative expression of Pin and Sin genes in $T_{1}$ silent plants and mean for their $T_{2}$ progeny of wheat cv. Kontesa (A) and triticale cv. Wanad (B); ${ }^{*}$ - significantly different from $T_{1}$.

well as in all lines compared with $\mathrm{T}_{1}$. The values for Pinb were less variable than for Pina in the $\mathrm{T}_{2}$ generation. The data of very weak or lack of Pinb and Pina silencing in $\mathrm{T}_{2}$ were correlated with the level of significantly weak or lack of Pinb-derived amiR, which ranged from 0 to $3.55 \times 10^{3}$ (compared to $0.3 \times 10^{6}$ to $68 \times 10^{6}$ in $\mathrm{T}_{1}$ ).

Relative expression of Sinb in $\mathrm{T}_{2}$ progeny of triticale $\mathrm{cv}$. Wanad ranged from 0.12 to 1.41 and for Sina from 0.11 to 1.38 (Figure 2D). About $1 / 4$; of the progeny out of 36 tested showed relative Sinb silencing up to 0.5 . For half of the progeny $\operatorname{Sin} b$ relative expression was from 0.5 to 1.0 and for the rest above 1 . The correlation between Sinb and Sina expression in $\mathrm{T}_{2}$ (Figure 2D) was positive and statistically significant $(r=-0.58 ; \alpha=0.01)$. The relative expression of Sinb and Sina in the $T_{2}$ progeny of seven silenced in $T_{1}$ transgenic plants of triticale increased significantly (KruskallWallis: $p=4.844 \mathrm{e}-05, \alpha=0.05$ ) (Figure 3B). The mean value for Sinb in $\mathrm{T}_{1}$ plants was $0.11( \pm 0.02)$ and for Sina was $0.15( \pm 0.06)$. The mean values for both Sinb and Sina genes in the $\mathrm{T}_{2}$ progeny were respectively $0.63( \pm 0.08)$ and $0.72( \pm 0.06)$. Otherwise these values were at a similar level (around $0.6-1.0$ ) in $\mathrm{T}_{2}$ progeny of non-silenced or weakly silenced $\mathrm{T}_{1}$ plants. As in the case of Pinb and Pina in wheat, the values of very weak or lack of Sinb and Sina silencing in $\mathrm{T}_{2}$ correlated with very weak or lack of relative expression of Pinb-derived amiR (from 0 to 13 -fold compared to calibrator sample).

The data of very low in $\mathrm{T}_{1}$ or similar to control in $\mathrm{T}_{2}$ transcript level of the Pina/Pinb genes in wheat and the Sina/Sinb genes in triticale were correlated with very low or similar to control level of 


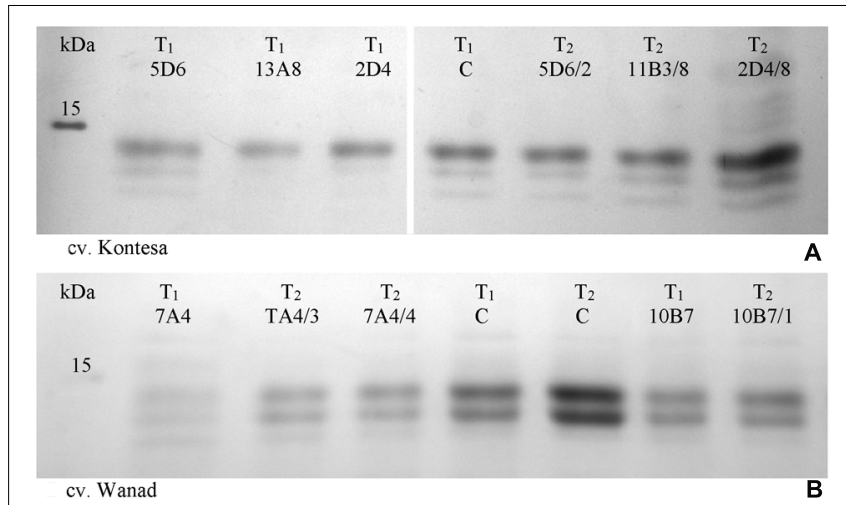

FIGURE 4 | SDS-PAGE fractionation of mature seed starch-associated proteins isolated from water washed starch from $T_{1}$ and $T_{2}$ progeny of wheat cv. Kontesa (A) and triticale cv. Wanad (B). C, control lines from $T_{1}$ and $\mathrm{T}_{2}$ generations; $\mathrm{M}$, molecular weight marker.

puroindoline a/puroindoline $b$ or secaloindoline a/secaloindoline $b$ (Figures 4A,B).

\section{Silencing of Pin and Sin Genes in $\mathrm{T}_{1}$ Determines Grain Hardness}

There were two main groups of $\mathrm{T}_{1}$ plants with silent Pin and Sin genes in both tested Triticeae species. In the first one, the significantly lower expression of Pin genes in wheat $\mathrm{cv}$. Kontesa and Sinb gene in triticale cv. Wanad were associated with increased grain hardness index, measured by the SKCS (KruskallWallis for Pina/SKCS: $p=2.287 \mathrm{e}-08, \alpha=0.05$; for Pinb/SKCS: $p=5.422 \mathrm{e}-09, \alpha=0.05$; for Sina/SKCS: $p=0.1136, \alpha=0.05$; and for Sinb/SKCS: $p=0.0009204, \alpha=0.05)$. In the second group, the relative values of SKCS in the $\mathrm{T}_{1}$ silent transgenics were not changed in wheat cv. Kontesa or were slightly lower in triticale cv. Wanad (Figure 5). Correlation coefficients between these two groups of wheat were 0.289 and 0.294 and for the two groups of triticale were 0.522 and 0.517 and were not significant.

The mean SKCS of the grains collected from all tested 46 lines of the $\mathrm{T}_{1}$ generation of wheat was $8 \%$ higher (not significant as confirmed by ANOVA: $p=0.109684, \alpha=0.05$ ) than in control plants, and the highest value was $124 \%$ of the control (Table 2). The mean SKCS in the grains from 28 tested $\mathrm{T}_{1}$ lines of triticale was $30 \%$ higher than in the control (not significant as confirmed by Kruskall-Wallis: $p=0.2159, \alpha=0.05$ ). The highest SKCS was $260 \%$ of the control.

The mean SKCS in the grains collected from all tested 46 transgenic lines of the $\mathrm{T}_{2}$ generation of wheat was $5 \%$ higher than in control lines, and from 28 tested $\mathrm{T}_{2}$ lines of triticale was $9 \%$ higher than in control.

\section{Total Protein Content Is Decreased in Wheat and Increased in Triticale Silenced Plants}

Mean total protein content in the same grains used for SKCS from silent $46 \mathrm{~T}_{1}$ lines of wheat cv. Kontesa was $14.65 \%( \pm 0.23)$ and was significantly lower than in the control $(16.40 \% \pm 0.35)$,
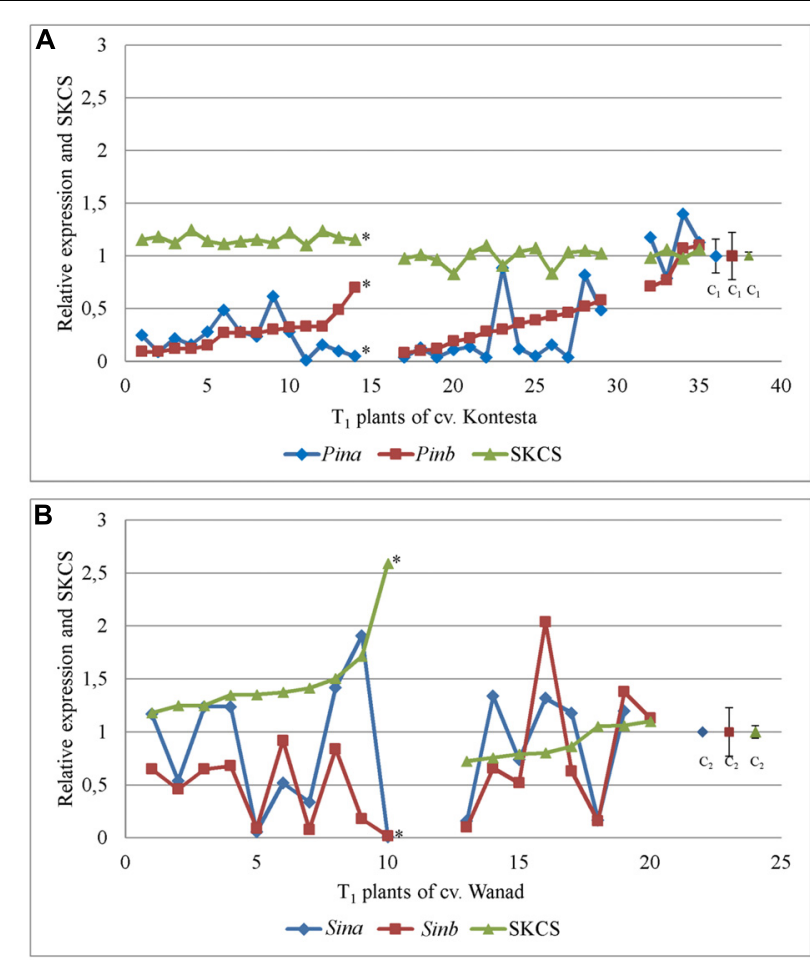

FIGURE 5 | Relative expression of Pin (A) and $\operatorname{Sin}$ (B) genes in 26 DAP kernels of $T_{1}$ plants silenced with Pinb-derived amiR versus hardness index [Single Kernel Characterization System (SKCS)] of their grains $\left(\mathrm{T}_{2}\right.$ progeny); * - the correlation between Pina or Pinb expression and SKCS in 1-14 plants of cV. Kontesa and between Sinb expression and SKCS in 1-10 plants of cV. Wanad was negative and significantly important at $\alpha=0.05$.

which was confirmed by ANOVA ( $p=0.037 ; \alpha=0.05$ ) (Table 3 ). Opposite data were obtained for triticale. Mean total protein content in the grains from 28 silent $\mathrm{T}_{1}$ was $13.74 \%( \pm 0.48)$ and was higher than in control $(12.81 \% \pm 0.30)$, but statistically not significant.

There was no correlation between grain hardness index and total protein in the $\mathrm{T}_{2}$ grains from $\mathrm{T}_{1}$ plants with silenced Pina and Pinb ( $r=-0.05848$ ) (Figure 6). However, a strong positive, statistically significant correlation between hardness index and total protein in triticale transgenics was observed $(r=0.68925$; $\alpha=0.05)$. Total protein content in triticale $\mathrm{cv}$. Wanad was increasing together with the increasing values of grain hardness.

\section{DISCUSSION}

The technology of gene silencing by amiRNAs exploits endogenous miRNA precursors to generate short, $21 \mathrm{nt}$ fragments of RNAs which are complementary to the target mRNA of the gene to direct gene silencing (Ossowski et al., 2008). In this research, a silencing cassette was designed based on the endogenous precursor of wheat miRNA Tae-miR164. The precursor was cloned in wheat by Yao et al. (2007). The main criteria for choosing this precursor were that the sequence of miRNA is conserved and the expression of miRNA is strong, 
TABLE 2 | Range and means of hardness index [Single Kernel Characterization System (SKCS)] and other parameters of grains collected from silent T $_{1}$ lines of wheat cv. Kontesa and triticale cv. Wanad.

\begin{tabular}{|c|c|c|c|c|c|c|}
\hline \multirow[t]{2}{*}{ Cultivar /vector/ } & \multirow[t]{2}{*}{ No. of lines } & \multicolumn{2}{|c|}{ SKCS } & \multirow[t]{2}{*}{ Weight (mg) (SE) } & \multirow[t]{2}{*}{ Moisture (\%) (SE) } & \multirow[t]{2}{*}{ Diameter (mm) (SE) } \\
\hline & & Range & Mean (SE) & & & \\
\hline \multicolumn{7}{|c|}{ cv. Kontesa } \\
\hline /amiPb/ & 46 & $56.57-84.69$ & 73.57 (0.95) & $39.47(0.53)$ & $8.00(0.45)$ & $3.05(0.13)$ \\
\hline control & 5 & $59.60-74.10$ & $68.07(2.48)$ & $42.15(0.65)$ & $8.19(0.49)$ & $3.04(0.10)$ \\
\hline \multicolumn{7}{|c|}{ cv. Wanad } \\
\hline /amiPb/ & 28 & $9.23-66.62$ & $32.83(2.67)$ & $43.13(1.40)$ & $8.44(0.48)$ & $2.92(0.14)$ \\
\hline control & 4 & $21.25-27.08$ & $25.20(1.05)$ & 47.89 (3.34) & $9.10(0.54)$ & $3.00(0.13)$ \\
\hline
\end{tabular}

TABLE 3 | Range and means of total protein content in the grains collected from silent $\mathrm{T}_{1}$ lines of wheat cv. Kontesa and triticale cv. Wanad.

\begin{tabular}{|c|c|c|c|c|c|}
\hline \multirow[t]{2}{*}{ Cultivar /vector/ } & \multirow[t]{2}{*}{ No. of lines } & \multicolumn{2}{|c|}{ Protein (\%) } & \multicolumn{2}{|c|}{ Protein/dry weight (\%) } \\
\hline & & Range & Mean (SE) & Range & Mean (SE) \\
\hline \multicolumn{6}{|c|}{ Kontesa } \\
\hline /amiPb/ & 46 & $10.09-17.86$ & $14.65(0.23)$ & $11.86-19.58$ & $16.27(0.35)^{*}$ \\
\hline control & 5 & 13.03-18.33 & $16.40(0.91)$ & 14.13-20.06 & $17.92(1.03)^{*}$ \\
\hline \multicolumn{6}{|c|}{ Wanad } \\
\hline /amiPb/ & 28 & $9.23-18.22$ & $13.74(0.48)$ & 10.09-20.19 & $15.17(0.53)$ \\
\hline Control & 4 & $12.15-13.58$ & $12.81(0.30)$ & $13.47-15.06$ & $14.17(0.30)$ \\
\hline
\end{tabular}

*Differences statistically significant (ANOVA: $p=0.037 ; \alpha=0.05$ ).

constitutive and not tissue specific. miR164 targets NAC transcription factors and is conserved among dicot and monocot plants. We have also confirmed strong expression of miR164 in various wheat organs (roots, leaves, inflorescences, seeds) at different developmental stages (Gasparis et al. unpublished).

Native fragments of miRNA of the precursor were replaced with the $21 \mathrm{nt}$ fragments complementary to the coding sequences of Pin and Sin genes chosen for silencing. This kind of strategy of designing amiRNAs by replacing the sequences of miRNA within the miRNA precursor without disrupting its structural features was originally proposed by Schwab et al. (2006). The WMD3 platform ${ }^{4}$ used to design the specific 21 nt fragments from Pin and $\operatorname{Sin}$ genes has a built-in algorithm which allowed to predict the optimal sequence of microRNA for the target genes. Such designing should provide high efficiency of silencing, specific to the cultivars of the two polyploid cereal species used in the experiments.

The Pina- and Pinb-derived amiR silencing cassettes were introduced into the wheat and triticale by Agrobacteriummediated transformation. This method of genetic transformation is the method of choice since we documented that the biolistic approach might stimulate strong off-target effects in the case of gene silencing by siRNAs (Zalewski et al., 2012). The similar negative effect of biolistic transformation compared to the Agrobacterium-mediated method was documented in the case of transgene expression in cereals (Dai et al., 2001; Travella et al.,

${ }^{4} \mathrm{http}: / /$ wmd3.weigelworld.org
2006). Unexpectedly, transformation efficiency was found to be dependent on the amiR cassette. Highly efficient transformation in both polyploid species, wheat and triticale, was observed in the case of Pinb-derived amiR and no or single transgenic plants were obtained in these species after transformation with the Pina-derived amiR cassette despite large numbers of embryos attempted and several repeats of experiments. In our opinion the chosen fragment of amiR for silencing of Pina and Sina genes might be lethal at the level of development of somatic embryos and/or plantlets, what will be further investigated.

However, we were able to obtain transgenic plants of wheat and triticale after applying the hpRNA type of cassette containing the full coding sequence of Pina or Sina, respectively (Gasparis et al., 2011, 2013).

Silencing of Pinb and Sinb in the $\mathrm{T}_{1}$ generation of wheat and triticale transgenic plants was highly efficient, attaining a maximum 94 and $98 \%$ decrease of gene expression, respectively. A high level of silencing (more than 50\%) was obtained for most of the $60 \mathrm{~T}_{1}$ plants tested in both species. Moreover, Pinb or Sinb gene silencing simultaneously decreased the expression of the second Pina or Sina gene, respectively, showing a strong, positive correlation. The level of silencing of Pinb or Pina and Sinb or Sina by siRNAs was not so high in the $\mathrm{T}_{1}$ generation of wheat and triticale, reaching over an $80 \%$ decrease of gene expression in single segregating plants (Gasparis et al., 2011, 2013). In those experiments, the effect of silencing was increased when silencing cassettes for both genes were used in cotransformation experiments. Similar to our results the impact of down-regulation 


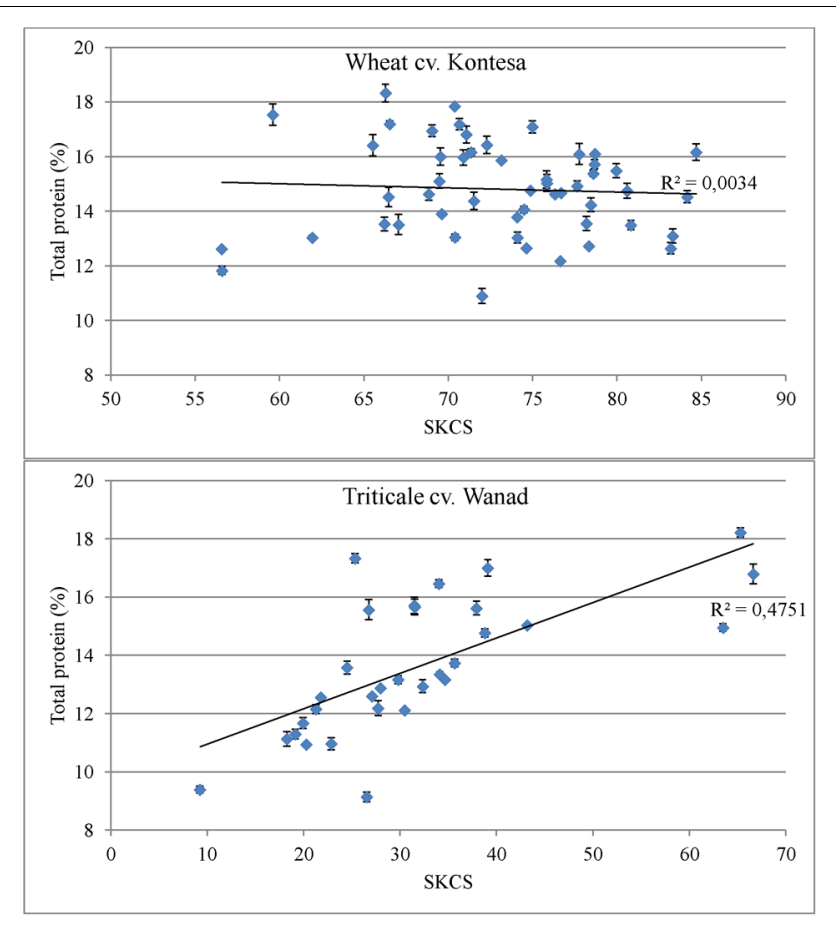

FIGURE 6 | Linear regression analysis between total protein content (\%) and grain hardness (SKCS) in wheat cv. Kontesa and triticale cv. Wanad.

of $S B E I I b$ in rice by amiRNA- and by hairpin RNA-mediated silencing has been reported (Butardo et al., 2011). The target gene expression was decreased much more in amiRNA silenced lines than in siRNA silenced lines.

Likewise, in the case of amiR, the silencing of one of the Pin or Sin genes simultaneously decreased the expression of the corresponding paralogue. Both wild-type Pin genes and wild-type puroindoline (PIN) proteins are required to determine soft-grain texture and mutation in either or both genes results in hard wheat (reviewed in Bhave and Morris, 2008; Nadolska-Orczyk et al., 2009; Pauly et al., 2013). The two-event model of co-operative action of both puroindolines explains why some of SNP-type of mutation may alter grain texture (Alfred et al., 2014). It is possible that this co-operative action of both proteins influence co-operative expression of both genes.

Although the Pinb-derived amiR silencing cassette is stably inherited in wheat and triticale, unexpectedly the effect of silencing of both Pin and both Sin genes by amiRs in most of the cases was not transmitted to the $\mathrm{T}_{2}$ generation or tended to decrease. Compatible with this lack of transmission of the silencing effect is the lack or very low expression of these amiRs in $\mathrm{T}_{2}$. To explain this, we are going to perform bisulfite sequencing of the amiRNA construct regions to identify methylation status affecting transcript level of the insert over the generations. The only data on the effect of amiR silencing in the $\mathrm{T}_{2}$ or later generations of cereal species were documented by Butardo et al. (2011) and Fahim et al. (2012). The expression of SBEIIb silenced by amiRNAs revealed more than a fivefold decrease in the homozygous $\mathrm{T}_{3}$ generation, and two $\mathrm{T}_{4}$ lines had a stably downregulated SBEIIb level and in one line the protein was almost undetectable (Butardo et al., 2011). In the case of WSMV virus resistance the inheritance of immunity was confirmed in the $\mathrm{T}_{2}$ generation (Fahim et al., 2012). The same Pin genes in wheat and Sin genes in triticale silenced by siRNAs using hpRNAi types of cassettes were stably down-regulated by over $90 \%$ in $\mathrm{T}_{2}$ to $\mathrm{T}_{4}$ and displayed the predicted, hard grain phenotype up to the $\mathrm{T}_{4}$ generation (Gasparis et al., 2011, 2013).

A high level of silencing of Pin and Sin genes and a corresponding high level of expression of Pinb-derived amiRs in $\mathrm{T}_{1}$ have been correlated with decreased content of puroindoline or secaloindoline proteins and increased grain hardness. All $\mathrm{T}_{1}$ plants of wheat tested were on average $8 \%$ harder than control lines, and the highest value was $124 \%$ of the control. The values of the hardness index were especially high for triticale lines typically representing soft grain species. The mean was 30\% higher than in the control, and the highest hardness index was 2.6 times higher than in control lines. The silencing of wheat Pin genes by Pinb-derived amiR in $\mathrm{T}_{1}$ lines had a stronger effect on grain hardness than in the case of siRNAs (Gasparis et al., 2011). Moreover, the hardness index in the case of silencing of triticale Sin genes by Pinb-derived amiR was especially high, contrary to the lack of change of this index after using the siRNA (Gasparis et al., 2013). Therefore we might suppose that in the case of triticale the silencing of Sin genes by siRNA was not sufficiently specific to determine grain hardness. In conclusion, we might state that silencing effects of Pin genes in allopolyploid wheat and especially Sin genes in allopolyploid triticale prove the high specificity of the amiRs, underlined also by others for diploid cereals (Warthmann et al., 2008; Carbonell et al., 2015). In the case of SBEIIb silencing in rice the amiRNA technique was more effective in producing more extreme starch properties than the hp-RNA technique (Butardo et al., 2011).

Silencing of Pin genes in wheat by amiRNAs correlated with decreased puroindoline content and increased grain hardness, which caused significant decrease of total protein content. The silencing of Sin genes in triticale by amiRNAs resulted in decreased secaloindoline content and spectacular increase of grain hardness. Contrary to the results in wheat, the triticale grain hardness positively correlated with total protein content. Opposite trends were observed for total protein content in grains of both species, when Pin and Sin genes were silenced with the siRNA type of RNAi cassettes (Gasparis et al., 2011, 2013). In the case of wheat, total protein content was increased, but it decreased in triticale. These discrepancies might be the result of different ways of silencing of Pin and Sin genes in both species and again underline the specificity of these two technologies.

\section{CONCLUSION}

We proved that amiRNA technology is highly efficient for silencing of endogenous, structural genes in allopolyploid cereal species, wheat and triticale. However, the main limitation might be stability of the silencing effect through generations. Silent $\mathrm{T}_{1}$ 
lines accumulated high levels of amiRNAs, which caused strong down-regulation of expression of the target genes. Moreover, the silencing was highly specific, displaying perfectly the predicted phenotypes in both species, induced by repression of the target genes. Although the transgenes/silencing cassettes were stably inherited through generations, the high expression of amiRNAs as well as the silencing effect was in most of the cases not transmitted to the $\mathrm{T}_{2}$ generation or in other tended to decrease. This result, different from some diploid cereals, might be dependent on more complex regulation of gene expression in allopolyploid species including endogenous miRNA activity. The effect of lack of inheritance of the silenced phenotype over the $T_{1}$ generation differs from silencing results of the same hardness genes by siRNAs, where the level of downregulation of target genes and the expected phenotype were proved up to the $\mathrm{T}_{4}$ generation. Summarizing both techniques, RNAi silencing by amiRNAs using specific precursor miRNA or by siRNAs with the hpRNAi type of cassettes efficiently down-regulated the target genes; however, amiRNAs are more specific, but the silencing signal might be interrupted through the generations. Otherwise, the effect of silencing by siRNAs is

\section{REFERENCES}

Alfred, R. L., Palombo, E. A., Panozzo, J. F., and Bhave, M. (2014). The cooperative interaction of puroindolines in wheat grain texture may involve the hydrophobic domain. J. Cereal Sci. 60, 323-330. doi: 10.1016/j.jcs.2014.06.001

Alvarez, J. P., Pekker, I., Goldshmidt, A., Blum, E., Amsellem, Z., and Eshed, Y. (2006). Endogenous and synthetic microRNAs stimulate simultaneous, efficient, and localized regulation of multiple targets in diverse species. Plant Cell 18, 1134-1151. doi: 10.1105/tpc.105.040725

Ameres, S. L., and Zamore, P. D. (2013). Diversifying microRNA sequence and function. Nat. Rev. Mol. Cell Biol. 14, 475-488. doi: 10.1038/nrm3611

Axtell, M. J. (2013). Classification and comparison of small RNAs from plants. Annu. Rev. Plant Biol. 64, 137-159. doi: 10.1146/annurev-arplant-050312120043

Baulcombe, D. (2004). RNA silencing in plants. Nature 431, 356-363. doi: 10.1038/ nature 02874

Bennett, M. D., and Smith, J. B. (1976). Nuclear-DNA amounts in angiosperms. Philos. Trans. R. Soc. Lond. B Biol. Sci. 274, 227-274. doi: 10.1098/rstb.1976.0044

Bettge, A. D., Morris, C. F., and Greenblatt, G. A. (1995). Assessing genotypic softness in single wheat kernels using starch granule-associated friabilin as a biochemical marker. Euphytica 86, 65-72. doi: 10.1007/Bf00035940

Bhave, M., and Morris, C. F. (2008). Molecular genetics of puroindolines and related genes: allelic diversity in wheat and other grasses. Plant Mol. Biol. 66, 205-219. doi: 10.1007/s11103-007-9263-7

Borges, F., and Martienssen, R. A. (2015). The expanding world of small RNAs in plants. Nat. Rev. Mol. Cell Biol. 16, 727-741. doi: 10.1038/nrm4085

Brodersen, P., and Voinnet, O. (2006). The diversity of RNA silencing pathways in plants. Trends Genet. 22, 268-280. doi: 10.1016/j.tig.2006.03.003

Butardo, V. M., Fitzgerald, M. A., Bird, A. R., Gidley, M. J., Flanagan, B. M., Larroque, O., et al. (2011). Impact of down-regulation of starch branching enzyme IIb in rice by artificial microRNA- and hairpin RNA-mediated RNA silencing. J. Exp. Bot. 62, 4927-4941. doi: 10.1093/jxb/err188

Carbonell, A., Carrington, J. C., and Daros, J. A. (2016). Fast-forward generation of effective artificial small RNAs for enhanced antiviral defense in plants. RNA Dis. 3:e1130. doi: 10.14800/rd.1130

Carbonell, A., Fahlgren, N., Mitchell, S., Cox, K. L. Jr., Reilly, K. C., Mockler, T. C., et al. (2015). Highly specific gene silencing in a monocot species by artificial microRNAs derived from chimeric miRNA precursors. Plant J. 82, 1061-1075. doi: $10.1111 /$ tpj. 12835

Carthew, R. W., and Sontheimer, E. J. (2009). Origins and mechanisms of miRNAs and siRNAs. Cell 136, 642-655. doi: 10.1016/j.cell.2009.01.035 stably inherited. Both techniques might be used for analysis of gene function in species with large and complex genomes, but only hpRNAi can be applied to obtain stable inherited lines with desired characteristics. A big advantage of both techniques is the possibility of obtaining silent lines differing in the level of silencing, which might not be achieved by other techniques such as gene editing.

\section{AUTHOR CONTRIBUTIONS}

SG designed and performed most of the experiments, MK and MP performed selected experiments and statistical analysis, WO coordination and codiscussion, AN-O conception and design, analysis and interpretation, and wrote the manuscript.

\section{ACKNOWLEDGMENT}

This research was supported by the Polish National Science Centre, grant UMO-2011/03/B/NZ9/01383.

Chen, L. Y., Cheng, X. F., Cai, J. Y., Zhan, L. L., Wu, X. X., Liu, Q., et al. (2016). Multiple virus resistance using artificial trans-acting siRNAs. J. Virol. Methods 228, 16-20. doi: 10.1016/j.jviromet.2015.11.004

Chen, M. L., Wei, X. J., Shao, G. N., Tang, S. Q., Luo, J., and Hu, P. S. (2012). Fragrance of the rice grain achieved via artificial microRNA-induced downregulation of OsBADH2. Plant Breed. 131, 584-590. doi: 10.1111/j.1439-0523. 2012.01989.x

Chen, X. (2009). Small RNAs and their roles in plant development. Annu. Rev. Cell Dev. Biol. 25, 21-44. doi: 10.1146/annurev.cellbio.042308.113417

Dai, S. H., Zheng, P., Marmey, P., Zhang, S. P., Tian, W. Z., Chen, S. Y., et al. (2001). Comparative analysis of transgenic rice plants obtained by Agrobacteriummediated transformation and particle bombardment. Mol. Breed. 7, 25-33. doi: 10.1023/A:1009687511633

Dumas, J. B. A. (1831). Procedes de l'analyse organic. Ann. Chim. Phys. 247, $198-213$.

FAO Statistics Division (2016). Food and Agricultural Commodities Production. Rome: FAO Statistics Division.

Fahim, M., Millar, A. A., Wood, C. C., and Larkin, P. J. (2012). Resistance to Wheat streak mosaic virus generated by expression of an artificial polycistronic microRNA in wheat. Plant Biotechnol. J. 10, 150-163. doi: 10.1111/j.1467-7652. 2011.00647.x

Felippes, F. F., Wang, J. W., and Weigel, D. (2012). MIGS: miRNA-induced gene silencing. Plant J. 70, 541-547. doi: 10.1111/j.1365-313X.2011.04896.X

Fu, D., Uauy, C., Blechl, A., and Dubcovsky, J. (2007). RNA interference for wheat functional gene analysis. Transgenic Res. 16, 689-701. doi: 10.1007/s11248-0079150-7

Gasparis, S., Orczyk, W., and Nadolska-Orczyk, A. (2013). Sina and Sinb genes in triticale do not determine grain hardness contrary to their orthologs Pina and Pinb in wheat. Bmc Plant Biol. 13:190. doi: 10.1186/1471-2229-13-190

Gasparis, S., Orczyk, W., Zalewski, W., and Nadolska-Orczyk, A. (2011). The RNA-mediated silencing of one of the Pin genes in allohexaploid wheat simultaneously decreases the expression of the other, and increases grain hardness. J. Exp. Bot. 62, 4025-4036. doi: 10.1093/jxb/err103

Ghildiyal, M., and Zamore, P. D. (2009). Small silencing RNAs: an expanding universe. Nat. Rev. Genet. 10, 94-108. doi: 10.1038/nrg2504

Goto, K., Kanazawa, A., Kusaba, M., and Masuta, C. (2003). A simple and rapid method to detect plant siRNAs using nonradioactive probes. Plant Mol. Biol. Report 21, 51-58. doi: 10.1007/BF02773396

Gromova, I., and Celis, E. J. (2006). "Protein detection in gels by silver staining: a procedure compatible with mass-spectrometry," in Cell Biology: A Laboratory Handbook, 3rd Edn, ed. E. J. Celis (Amsterdam: Elsevier), 219-223. 
Hamilton, A. J., and Baulcombe, D. C. (1999). A species of small antisense RNA in posttranscriptional gene silencing in plants. Science 286, 950-952. doi: 10.1126/ science.286.5441.950

Kamthan, A., Chaudhuri, A., Kamthan, M., and Datta, A. (2015). Small RNAs in plants: recent development and application for crop improvement. Front. Plant Sci. 6: 208. doi: 10.3389/fpls.2015.00208

Kis, A., Tholt, G., Ivanics, M., Varallyay, E., Jenes, B., and Havelda, Z. (2016). Polycistronic artificial miRNA-mediated resistance to wheat dwarf virus in barley is highly efficient at low temperature. Mol. Plant Pathol. 17, 427-437. doi: $10.1111 / \mathrm{mpp} .12291$

Laemmli, U. K. (1970). Cleavage of structural proteins during the assembly of the head of bacteriophage T4. Nature 227, 680-685. doi: 10.1038/227680a0

Lawrence, R. J., and Pikaard, C. S. (2003). Transgene-induced RNA interference: a strategy for overcoming gene redundancy in polyploids to generate lossof-function mutations. Plant J. 36, 114-121. doi: 10.1046/j.1365-313X.2003. 01857.x

Li, T., Ma, L., Geng, Y., Hao, C., Chen, X., and Zhang, X. (2015). Small RNA and degradome sequencing reveal complex roles of miRNAs and their targets in developing wheat grains. PLOS ONE 10:e0139658. doi: 10.1371/journal.pone. 0139658

Llave, C., Xie, Z. X., Kasschau, K. D., and Carrington, J. C. (2002). Cleavage of Scarecrow-like mRNA targets directed by a class of Arabidopsis miRNA. Science 297, 2053-2056. doi: 10.1126/science.1076311

Martin, R. C., Liu, P. P., Goloviznina, N. A., and Nonogaki, H. (2010). microRNA, seeds, and Darwin?: diverse function of miRNA in seed biology and plant responses to stress. J. Exp. Bot. 61, 2229-2234. doi: 10.1093/jxb/erq063

Mette, M. F., Kanno, T., Aufsatz, W., Jakowitsch, J., van der Winden, J., Matzke, M. A., et al. (2002). Endogenous viral sequences and their potential contribution to heritable virus resistance in plants. EMBO J. 21, 461-469. doi: 10.1093/emboj/ 21.3.461

Meyers, B. C., Axtell, M. J., Bartel, B., Bartel, D. P., Baulcombe, D., Bowman, J. L., et al. (2008). Criteria for annotation of plant MicroRNAs. Plant Cell 20, 3186-3190. doi: 10.1105/tpc.108.064311

Murray, M. G., and Thompson, W. F. (1980). Rapid isolation of high molecularweight plant DNA. Nucleic Acids Res. 8, 4321-4325. doi: 10.1093/nar/8.19. 4321

Nadolska-Orczyk, A., Gasparis, S., and Orczyk, W. (2009). The determinants of grain texture in cereals. J. Appl. Genet. 50, 185-197. doi: 10.1007/Bf03195672

Nadolska-Orczyk, A., Przetakiewicz, A., Kopera, K., Binka, A., and Orczyk, W. (2005). Efficient method of Agrobacterium-mediated transformation for Triticale (x Triticosecale Wittmack). J. Plant Growth Regul. 24, 2-10. doi: 10. 1007/s00344-004-0046-y

Ossowski, S., Schwab, R., and Weigel, D. (2008). Gene silencing in plants using artificial microRNAs and other small RNAs. Plant J. 53, 674-690. doi: 10.1111/ j.1365-313X.2007.03328.x

Park, W., Li, J. J., Song, R. T., Messing, J., and Chen, X. M. (2002). CARPEL FACTORY, a Dicer homolog, and HEN1, a novel protein, act in microRNA metabolism in Arabidopsis thaliana. Curr. Biol 12, 1484-1495. doi: 10.1016/ S0960-9822(02)01017-5

Pauly, A., Pareyt, B., Fierens, E., and Delcour, J. A. (2013). Wheat (Triticum aestivum L. and T. turgidum L. ssp durum) Kernel hardness: I. current view on the role of puroindolines and polar lipids. Compr. Rev. Food Sci. Food Saf. 12, 413-426. doi: 10.1111/1541-4337.12019

Pfaffl, M. W. (2001). A new mathematical model for relative quantification in real-time RT-PCR. Nucleic Acids Res. 29, e45. doi: 10.1093/nar/29.9.e45

Prescott, A., and Martin, C. (1986). A rapid method for the quantitative assessment of levels of specific mRNAS in plants. Plant Mol. Biol. Report. 4, 219-224. doi: $10.1007 / \mathrm{bf} 02675414$
Przetakiewicz, A., Karas, A., Orczyk, W., and Nadolska-Orczyk, A. (2004). Agrobacterium-mediated transformation of polyploid cereals. The efficiency of selection and transgene expression in wheat. Cell. Mol. Biol. Lett. 9, 903-917.

Przetakiewicz, A., Orczyk, W., and Nadolska-Orczyk, A. (2003). The effect of auxin on plant regeneration of wheat, barley and triticale. Plant Cell Tissue Organ Cult. 73, 245-256. doi: 10.1023/A:1023030511800

Reinhart, B. J., Weinstein, E. G., Rhoades, M. W., Bartel, B., and Bartel, D. P. (2002). MicroRNAs in plants. Genes Dev. 16, 1616-1626. doi: 10.1101/gad.1004402

Rogers, K., and Chen, X. M. (2013). Biogenesis, turnover, and mode of action of plant microRNAs. Plant Cell 25, 2383-2399. doi: 10.1105/tpc.113. 113159

Schwab, R., Ossowski, S., Riester, M., Warthmann, N., and Weigel, D. (2006). Highly specific gene silencing by artificial microRNAs in Arabidopsis. Plant Cell 18, 1121-1133. doi: 10.1105/tpc.105.039834

Tester, M., and Langridge, P. (2010). Breeding technologies to increase crop production in a changing world. Science $327,818-822$. doi: $10.1126 /$ science. 1183700

Tiwari, M., Sharma, D., and Trivedi, P. K. (2014). Artificial microRNA mediated gene silencing in plants: progress and perspectives. Plant Mol. Biol. 86, 1-18. doi: 10.1007/s11103-014-0224-7

Travella, S., Klimm, T. E., and Keller, B. (2006). RNA interference-based gene silencing as an efficient tool for functional genomics in hexaploid bread wheat. Plant Physiol. 142, 6-20. doi: 10.1104/pp.106.084517

van der Krol, A. R., Mur, L. A., Beld, M., Mol, J. N., and Stuitje, A. R. (1990). Flavonoid Genes in Petunia: addition of a limited number of gene copies may lead to a suppression of gene-expression. Plant Cell. 2, 291-299. doi: 10.1105/ tpc.2.4.291

Varkonyi-Gasic, E., Wu, R. M., Wood, M., Walton, E. F., and Hellens, R. P. (2007). Protocol: a highly sensitive RT-PCR method for detection and quantification of microRNAs. Plant Methods 3: 12. doi: 10.1186/1746-4811-3-12

Warthmann, N., Chen, H., Ossowski, S., Weigel, D., and Herve, P. (2008). Highly specific gene silencing by artificial miRNAs in rice. PLOS ONE 3: e1829. doi: 10.1371/journal.pone.0001829

Waterhouse, P. M., and Helliwell, C. A. (2003). Exploring plant genomes by RNA-induced gene silencing. Nat. Rev. Genet. 4, 29-38. doi: 10.1038/nrg982

Xu, P., Zhang, Y., Kang, L., Roossinck, M. J., and Mysore, K. S. (2006). Computational estimation and experimental verification of off-target silencing during posttranscriptional gene silencing in plants. Plant Physiol. 142, 429-440. doi: $10.1104 /$ pp.106.083295

Yao, Y., Guo, G., Ni, Z., Sunkar, R., Du, J., Zhu, J. K., et al. (2007). Cloning and characterization of microRNAs from wheat (Triticum aestivum L.). Genome Biol. 8:R96. doi: 10.1186/gb-2007-8-6-r96

Zalewski, W., Orczyk, W., Gasparis, S., and Nadolska-Orczyk, A. (2012). HvCKX2 gene silencing by biolistic or Agrobacterium-mediated transformation in barley leads to different phenotypes. BMC Plant Biol. 12:206. doi: 10.1186/1471-2229$12-206$

Conflict of Interest Statement: The authors declare that the research was conducted in the absence of any commercial or financial relationships that could be construed as a potential conflict of interest.

Copyright (c) 2017 Gasparis, Kała, Przyborowski, Orczyk and Nadolska-Orczyk. This is an open-access article distributed under the terms of the Creative Commons Attribution License (CC BY). The use, distribution or reproduction in other forums is permitted, provided the original author(s) or licensor are credited and that the original publication in this journal is cited, in accordance with accepted academic practice. No use, distribution or reproduction is permitted which does not comply with these terms. 